\title{
C-20 HIGH-FREQUENCY SEA-LEVEL CHANGES CONTROL THE RECENT SEDIMENTARY ARCHITECTURE OF A SMALL MODERN TURBIDITE SYSTEM
}

\author{
FERNANDO PÉREZ-BELZUZ, BELEN ALONSO and ANICK GALIMONT \\ CSIC, Instituto de Ciencias del Mar, Dept. Geología Marina y Oceanografía Física, \\ Paseo Juan de Borbón s/n., 08039 Barcelona, Spain
}

\begin{abstract}
SUMMARY
The morphology, sedimentary architecture and recent sedimentary evolution of the Calahonda Turbidite System (Alboran Sea, SW Mediterranean) was established through the analysis of ultra-high resolution seismic profiles, swath bathymetry and sediment cores. This small turbidite system $\left(180 \mathrm{~km}^{2}\right)$ is fed by four canyons and several gullies that lead to the formation of ten channel-levee complexes constituted by sandy lens-shaped bodies, silty-sandy channel-fill bodies, overbank deposits and muddy drape deposits. Because the canyons are not incised in the shelf, high frequency sea-level changes $\left(4^{\text {th }}\right.$ order) have controlled the recent sedimentary evolution of this system, which is characterised by three evolutive phases: (1) widespread erosion and deposition of sandy lens bodies; (2) agradation of channellevee complexes; (3) formation of a muddy drape level.
\end{abstract}

\section{INTRODUCTION}

The study of the Calahonda Turbidite System is useful because it develops architectural elements which represent potential hydrocarbon reservoirs (sandy channel-fill bodies and sandy lens-shaped bodies) that are of the same scale as similar features described from outcrop studies. This depositional system has developed in a semi-enclosed area during the Quaternary in a tectonically active setting characterised by a very narrow shelf $(2-4 \mathrm{~km}$ wide), slope $(6 \mathrm{~km})$ and base-of-slope $(8 \mathrm{~km}$ wide). It is small (18 km maximum length, $180 \mathrm{~km}^{2}$ area) and develops in shallow waters (20 $\mathrm{m}$ to $850 \mathrm{~m}$ depth), receiving sediment from several small rivers ( $<15 \mathrm{~km}$ long) (Fig. 1).

The objectives of this paper are to determine: (1) the ultra-high resolution seismic architecture and sedimentology of the recent deposits of the Calahonda Turbidite System; and (2) the recent sedimentary evolution and the influence of high-frequency $\left(4^{\text {th }}\right.$-order) sea-level changes.

\section{METHODS}

The data were collected using the RV García del Cid in 1996 (MAYC Cruise) and the RV Hespérides in 1998 (MATER-I Cruise). Bathymetric mapping was undertaken with a SIMRAD EM-12 echosounder. Ultra-high resolution seismic profiles were obtained with a Bentech TOPAS (Topographic Parametric System). 37 sediment samples belonging to three sediment cores were split, described and sampled (Fig. 1). Textural parameters were obtained and the sand fraction, carbonate content and the sedimentary structures were analysed.

\section{RESULTS}

\section{Drainage pattern and seismic architecture}

The drainage pattern of the Calahonda Turbidite System includes four canyons, several gullies and thirteen channels. The canyons erode the upper slope and have maximum widths of between 1.75 and $2.5 \mathrm{~km}$ and maximum depths of between 50 and $90 \mathrm{~m}$. The gullies erode the middle slope and have a maximum width of $1.25 \mathrm{~km}$ and a maximum depth of $25 \mathrm{~m}$. The straight channels (sinuosity 1.1 to 1.2) are incised in the lower slope and in the base of slope and have maximum widths of 500 to $1000 \mathrm{~m}$ and maximum depths of 15 to $40 \mathrm{~m}$ (Fig. 1). 
The ultra-high resolution architecture of the upper seismic section reveals the development of ten channel-levee complexes with a maximum length of $15 \mathrm{~km}$ and a total width of $14 \mathrm{~km}$. Each complex is narrow ( 1 to $4 \mathrm{~km}$ ) and has a maximum thickness of between 20 and $75 \mathrm{~ms}$ (TWTT). They are formed by channel-fill deposits, overbank deposits, lens-shaped bodies and drape deposits. The channel-fill deposits (10-35 ms thick) are characterised by chaotic seismic facies. The overbank deposits form distinct levees and are constituted by semitransparent and down-lapping discontinuous stratified seismic facies. The lens-shaped bodies (maximum thickness $20 \mathrm{~ms}$, maximum width $5 \mathrm{~km}$ ), which are located in the distal reaches and in the lower part of the channel-levee complexes, are characterised by semitransparent seismic facies. The drape deposits (2-3 ms thick), which have developed in the uppermost part of the channel-levee complexes forming a tabular level that drapes both channel and levee deposits, are formed by semitransparent and discontinuous stratified seismic facies (Fig. 2).

\section{Sedimentological analysis}

The sedimentological analysis was performed to characterise the channel-fill deposits which represent one of the most important reservoirs likely to develop in a turbidite system. Two sedimentary facies were identified: channel-fill facies and drape facies. The channel-fill facies was recovered in the lower part of the sediment cores (below $160-200 \mathrm{~cm}$ ) and is characterised by sandy and silty turbidites ( $\mathrm{Ta}, \mathrm{Tb}, \mathrm{Tc}$ and $\mathrm{Td})(15-50 \mathrm{~cm}$ thick) in the lower slope and upper base-of-slope (557-692 $\mathrm{m} \mathrm{depth}$ ) and by sandy turbidites $(\mathrm{Ta}$ and $\mathrm{Tb})(5-10 \mathrm{~cm}$ thick) and silty-sandy debris flow deposits $(2-10 \mathrm{~cm}$ thick) in the lower base-of-slope (743 m depth). The drape facies was identified in the upper part of the sediment cores $(0$ to $160-200 \mathrm{~cm})$ and correlates with the drape deposits identified in the TOPAS seismic profiles. This facies is characterised in the lower slope (557 m depth) by muddy turbidites (Te) $(200 \mathrm{~cm}$ thick) and in the base-of-slope (743 m depth) by muddy turbidites (Te), mixed muds and hemipelagic muds (160 cm thick).

\section{SEDIMENTARY EVOLUTION AND HIGH-FREQUENCY SEA-LEVEL CHANGES}

The recent sedimentary evolution of the Calahonda Turbidite System is represented by three phases: (1) widespread erosion and deposition of sandy lens bodies; (2) agradation of channel-levee complexes; and (3) formation of a muddy drape level (Fig. 2). Phase 1 starts with a widespread erosive phase and the formation of lens-shaped bodies with seismic facies (blanking effect and semitransparent seismic facies in the TOPAS profiles), suggesting a sandy composition. These sandy lens-shaped bodies would be formed due to the action of high-energy gravity flows produced as a consequence of a sharp increase in the sedimentary activity of the canyons (Fig. 2). In Phase 2 the agradation of channel-levee complexes and the building of well-developed levees suggests the transfer of higher volume muddier turbidity flows. The over-spilling of the fine fraction would lead to the building of the levees, whereas the coarsest sediments are deposited forming sandy-silty channel fill-deposits (Fig. 2). The channels also occasionally transfer silty-sandy debris flows. In Phase 3 drape deposits covering both the channels and the levees are formed. The channelised gravity flows stop simultaneously in every channel and levee growth ends. Instead, unchannelised muddy gravity flows and hemipelagic sedimentation start to dominate in the channel-levee complexes and this situation continues to the present (Fig. 2).

The high frequency sea-level changes represent the main controlling factor of the sedimentary evolution of the Calahonda Turbidite System. The onset of the last high-frequency ( $4^{\text {th }}$-order) sea-level fall (ca. 120000 years BP) during Phase 1 would lead to a migration of the coastline towards the shelf edge, favouring the triggering of high-energy gravity flows. Phase 2 would occur during the late sea-level fall, lowstand and early sea-level rise, when the river mouths would be located seaward of the shelf edge, feeding the canyon heads directly. Thus, the canyon would transfer high-volume muddy and mixed channelised turbidity flows towards the channel-levee complexes. Finally, during Phase 3 drape deposits are generated as a consequence of the Holocene sea-level rise and highstand. Because the canyons are not incised on the shelf, the landward migration of the coastline would disconnect the canyon heads from the sediment sources, avoiding the transfer of high-energy channelised gravity flows. 


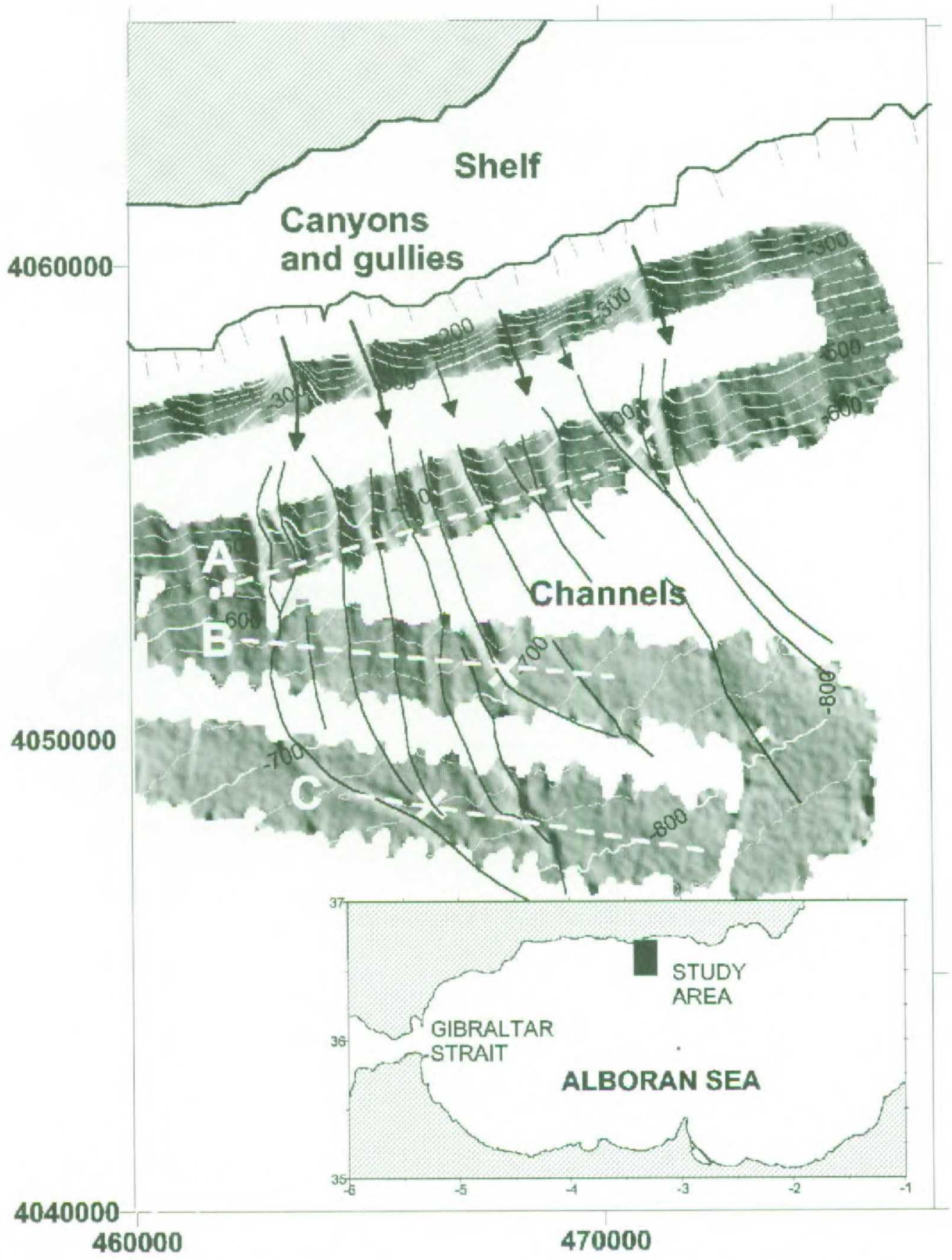

Figure 1. High-resolution bathymetric map (in metres) and shadow relief map (EM-12) showing the drainage pattern of the Calahonda Turbidite System. The open white circles indicate the location of the sediment cores. The thick black arrows correspond to canyons and the thin black arrows to gullies. The thin black lines show the location of the channels. The dashed white lines indicate the location of the TOPAS seismic profiles (A, B and C) which are illustrated in Figure 2. 


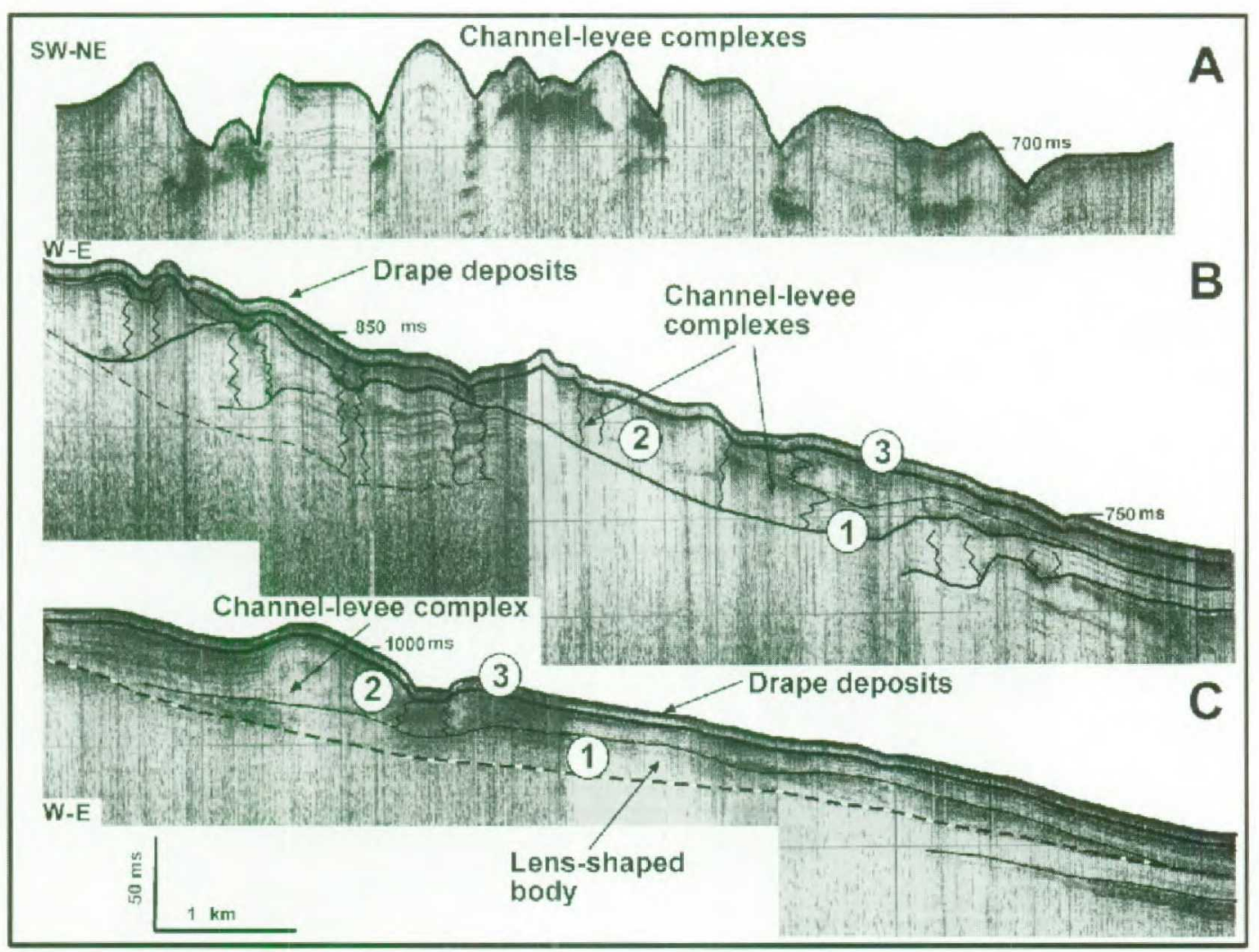

Figure 2. Ultra-high resolution TOPAS seismic profiles which are located in the lower slope (A) and in the base-ofslope (B and C). These seismic profiles show the recent seismic architecture and the sedimentary evolution of the Calahonda Turbidite System. The numbers (1,2 and 3) indicate the three phases of the sedimentary evolution of this turbidite system; ms, milliseconds (TWTT). Location of the seismic profiles in the Figure 1. 